\title{
Only the military can get the Ebola epidemic under control: MSF head
}

\author{
Sophie Arie talks to MSF's president, Joanne Liu, about her frustrations at the slow international \\ response to the Ebola epidemic
}

\section{Sophie Arie freelance journalist, London, UK}

Médecins Sans Frontières (MSF), the humanitarian medical charity, has been on the front lines of the Ebola epidemic since it began. It has had a major role in the international effort to control the outbreak, caring for two thirds of the 8000 people in Guinea, Sierra Leone, and Liberia who have been infected. But in early September, after six months of battling Ebola in vain, and with the death toll mounting exponentially, MSF effectively admitted defeat and said that it would take major military mobilisation by wealthy countries with biohazard expertise, not just international aid, to stop the disease. The charity had doubled its staff, MSF's president, Joanne Liu, told the UN members, but it still was overwhelmed.

Liu, a Canadian paediatrician who has worked for MSF in war zones and natural disasters for the past 18 years, called upon UN members to dispatch their disaster response teams, backed by the full weight of your logistical capabilities. "Without this deployment, we will never get the epidemic under control," she said. ${ }^{1}$

Peter Piot, director of the London School of Tropical Medicine and Hygiene and the microbiologist who first identified the Ebola virus in 1976, also called in September for a "quasi military intervention." He suggested that a major UN peacekeeping force should be deployed to Sierra Leone and Liberia, with huge donations of beds, ambulances, and trucks as well as an army of clinicians, doctors, and nurses.

The message came as the numbers of deaths from Ebola began to spiral, particularly in Liberia. There have been over 3800 reported deaths in the region, according to the latest World Health Organization figures, $40 \%$ of which have been recorded since September. ${ }^{2}$ WHO has estimated that there could be 20 000 infections before the outbreak is brought under control, and the US Centers for Disease Control has predicted that, in a worst case scenario, as many as 1.4 million may be infected by the end of January. ${ }^{3}$ As the economies and health infrastructures of the three countries, home to over 22 million people, risk total collapse, the UN Security Council declared the outbreak was a threat to international peace and security.

\section{Limited response}

Yet a month after the first calls for military deployment, forces are only now starting to be mobilised in any numbers. The US, UK, Germany, and France have responded, although not exactly as Liu had hoped they would. The US has said it will send 4000 troops to build new isolation units and treatment facilities in Liberia, a country created by US citizens as a colony for former African American slaves. But President Obama has made it clear that US troops will not be staffing those units and coming into contact with Ebola patients. The UK has pledged to send 750 troops to establish new Ebola treatment centres in Sierra Leone, its former colony, and a training academy for those working in treatment centres. Around 5000 German troops have volunteered to work in west Africa but they have not yet been deployed, and the government has now admitted that it would not have the resources to fly any troops home for treatment should they become infected.

So far no other countries have offered their armed forces, and President Obama warned in early October, if most countries choose to remain on the sidelines and watch the US do the bulk of the military work, the outbreak will continue to be a global threat. $^{4}$

Liu says she is exasperated at the slow, hands-off response. "Countries are approaching this with the mindset of going to war," she says. "Zero risk. Zero casualties."

Liu describes the current military efforts as the equivalent, in public health terms, of airstrikes without boots on the ground. Pledges of equipment and logistical support are helpful- "The military are the only body that can be deployed in the numbers needed now and that can organise things fast." But there is still a massive shortage of qualified and trained medical staff on the ground. "You need to send people not stuff and get hands on, not try to do this remotely," Liu says, "Local doctors have been extremely brave, but we are running out of staff and that is why we are asking for a major workforce to deploy."

Since the 9/11 attack on New York's twin towers, Western countries have developed military and civilian biohazard teams 
to protect their populations against a possible bioterrorist attack. Liu had hoped that these could be deployed to west Africa. "I think with the massive investment and knowing how much they are afraid of bioterrorism, they have some knowhow about highly contagious diseases."

MSF is not alone in thinking that what's needed in west Africa is the same level of Western military involvement that there would be in the event of a major bioterrorist attack on home soil.

The European Commission's humanitarian arm (ECHO) has been pushing for military medical intervention, its health adviser, Jorge Castilla-Echenique, told Reuters in Dakar in September. ${ }^{5}$

"The European Commission wants [US] Army and Seal protection teams to come here and produce an air bridge to keep the health workers and aid flowing. I'm talking about a MASH like operation," said Castilla-Echenique, referring to US mobile army surgical hospitals that can serve as fully functional health facilities.

"The problem with the military is that a treatment centre [50 beds] may cost $€ 7 \mathrm{~m}[£ 5.5 \mathrm{~m} ; \$ 9 \mathrm{~m}]$ over one year. But if it's done by the US military, it's going to cost $€ 70 \mathrm{~m}$, because they are going to come with their own bubble so they won't get sick," he said.

\section{Health workers at risk}

It is not entirely clear how many healthcare workers, national or international, are currently working with Ebola patients in west Africa. MSF now has 2800 national staff and 200-300 international staff working across the three countries. Fourteen staff, including one international worker, have become ill, eight of whom have died. An assessment by the Office for the Coordination of Humanitarian Affairs, based on WHO's prediction of 20000 infections, calculates that 178 doctors and nurses would be needed. If the CDC's predictions are right, the number would be many times higher.

Despite a major international effort launched by WHO in July large numbers of health professionals are still working without proper protection or sanitation. Almost 200 healthcare workers are known to have died, including the leading experts in each country, and many of those remaining are now too afraid to go to work or have reportedly left the country.

Troops are arriving just as a parallel global effort to accelerate the process for testing and approving experimental drugs and vaccines is getting under way. In November, clinical trials of several candidate treatments are planned to begin on Ebola patients in the region, with a view to obtaining results by December and producing the drugs for distribution early next year, should the trials prove successful. Potential vaccines are also being tested. Though she recognises that the availability of a vaccine in large quantities could be a "gamechanger," Liu is concerned that the possibility that a new drug or vaccine could stop Ebola in its tracks may take the pressure off the global community to take more action to save lives in the meantime.

"We cannot let this give people a reason not to deploy more resources to fight this on the ground," she says. "Everyone is looking for excuses to not deploy because they are so scared."

While the details of those trials are still being ironed out-and we wait to find out whether the candidate vaccines and drugs will prove safe and effective-MSF warns that there are huge ethical decisions still to be made. Not least is the question of who should receive the vaccines if, as is almost certain to be the case, there are not initially enough to go round.
"Right now everybody is reflecting on this. Who do we privilege if vaccines can be produced in time for this outbreak but there are not enough for everyone. Pregnant women? Those who've had contact with infected people? Health workers?"

Although MSF is keen to be involved in efforts to develop treatments and vaccines for the disease, it does not believe that a vaccine is a solution to the current outbreak because no manufacturer would be able to produce enough for the entire populations of the three countries in one go.

\section{Tensions with WHO}

Besides providing medical help to those in need worldwide, MSF, which was founded by a group of French doctors to provide assistance to refugees during the 1967-70 Biafran war, has built itself as a prominent voice of absolute humanitarian ideals. Although it works closely around the world with the UN and with individual states, it is often one of WHO's harshest critics. Liu, speaks of a "healthy tension" between MSF and the WHO, which she has accused of being woefully slow to react to the Ebola outbreak.

MSF was ringing alarm bells in spring about the Ebola outbreak being out of control, but it took until August for WHO to recognise the scale of the threat and declare a "health emergency of international concern," a legal mechanism that flips switches in the international community so that funding and expertise are mobilised faster and protection measures are put in place.

"Every meeting where we've been trying to advise something, it's been a challenge," Liu says. "We had the feeling people didn't understand what we were talking about. They were just looking at the figures. When you look at the figures in absolute [compared with other diseases that kill many more people] people say 'why are we getting so excited?' But Ebola has completely killed the infrastructure of these countries. It is attacking the state and the health structures. We cannot afford to let that continue."

"I am running out of words to convey the sense of urgency. The despair is so huge and the indifference so incredible."

Guinea, Sierra Leone and Liberia, three of the 12 least developed countries on earth, ${ }^{6}$ are countries many people outside Africa could not have placed on a map until the Ebola outbreak began.

Liu recognises that the capacity of wealthy countries to care and respond to distant crises has been stretched like never before in recent months (MSF has never deployed as many staff in as many countries as in 2014). Crises in Syria, Iraq, Ukraine, and Gaza mean that when MSF urged countries to do more about Ebola, the message came back that "our plate is full."

But she says, lack of leadership not lack of money has been the real problem. What the Ebola crisis has shown is that the global system for coping with potential health emergencies has omitted to create a clear chain of command.

"What is the international governance order? Who feels responsible?" she asks. "At the moment, no one feels responsible. "WHO considers itself to be a technical agency answering to member states. Somehow people left it to a private organisation to take the lead. There's something wrong there." In September, after the UN Security Council declared Ebola had become a global security threat, the United Nations created its first ever UN emergency health mission, the Mission for Ebola Emergency Response (UNMEER). ${ }^{7}$ The mission will be headed by British doctor David Nabarro, a former system coordinator for avian and human influenza for the UN. It aims 
to coordinate the international efforts to stop Ebola and has its headquarters in Ghana.

Competing interests: I have read and understood BMJ policy on declaration of interests and have no relevant interests to declare.

Provenance and peer review: Commissioned; not externally peer reviewed.

1 MSF international president: United Nations special briefing on Ebola, 2 September 2014 www.msf.org.uk/node/26146.
2 WHO. Ebola response roadmap situation report 8 October 2014. http://apps.who.int/iris/ bitstream/10665/136020/1/roadmapsitrep_8Oct2014_eng.pdf?ua=1.

3 McCarthy M. Liberia and Sierra Leone could see 1.4 million Ebola cases by January. BMJ 2014;349:g5866

4 McCarthy M. Obama calls on other nations to step up their efforts to end Ebola outbreak. BMJ 2014;349:96094.

5 Hussain M. MSF calls for military medics to help tackle west Africa Ebola. Thomas Reuters Foundation, 2 September 2014. www.trust.org/item/20140902150401-egnh8/.

6 UNDP. Human development index. http://hdr.undp.org/en/content/human-developmentindex-hdi.

7 UN Mission for Ebola Emergency Response. www.un.org/ebolaresponse/mission.shtml.

Cite this as: BMJ 2014;349:g6151

(C) BMJ Publishing Group Ltd 2014 